\title{
Developing And Implementing A Measure Of Sustainability For Workforce And Economic Development Projects In Northeast Pennsylvania
}

\author{
David M. Gilfoil Ph.D., DeSales University, USA
}

Robert T. Brill Ph.D., Moravian College, USA

\begin{abstract}
As part of a Wall Street West (WSW) grant, a project team was assembled to investigate the effectiveness of other WSW grantees working on various projects to impact the long term economic development of the financial services sector of the Northeast Pennsylvania (NEPA) corridor. Because sustainability of grant work was deemed critical by project leaders, a literature search was undertaken to identify factors that contribute to sustainability. Twelve factors were culled from the literature, reviewed with WSW executives and project grantees, and ultimately combined (using a BARS assessment methodology) to form an economic or workforce development Sustainability Index. This paper reviews the logic and the steps taken to develop the Sustainability Index, discusses the validity and reliability of the instrument, and shows how it was used to measure and report the relative importance of sustainability factors in economic development activities. The authors issue a call to action to further develop and refine the instrument across a variety of application venues.
\end{abstract}

Keywords: sustainability index; economic development; financial services; BARS assessment; sustainability; evaluation criteria; workforce development; measurement

\section{INTRODUCTION}

n November, 2008, as part of a Wall Street West (WSW) grant, a project team from the Lehigh Valley Research Consortium (LVRC) was assembled to investigate the effectiveness of other WSW grantees working on various projects funded to impact the long term workforce and economic development of the financial services sector of the Northeast Pennsylvania corridor. Because WSW executives were concerned about sustainability of funded project activities, LVRC set out to (a) develop a definition of sustainability (b) research the literature to identify factors that impact sustainability (c) develop a measure of sustainability and (d) implement the sustainability measure by assessing individual project initiatives funded to impact the development objectives.

For purposes of our grant work, sustainability was defined as:

The long term viability of WSW grantee plans, programs and initiatives within the financial services community in northeastern PA, which will expand the economic, educational and vocational capacities of the region.

\section{Sustainability Factors}

A review of the literature was conducted across several domains in an attempt to identify factors driving sustainability of project or work related activities. Relevant work from the airline industry (Yilmaz, 2008), healthcare (Shediac-Rizkallah \& Bone, 1998) and a host of other corporate and educational domains (Adelman \& Taylor, 2003; Brown, 1998; Found, Beale, \& Rich, 2006; Miller, 2005; Scheirer, 2005; VanMarrewijk, 2003) was 
reviewed. From this body of work, 23 characteristics of project or work sustainability were identified and grouped into 12 "conceptually" orthogonal sustainability factors as follows:

1. Collaboration \& Partnerships

2. $\quad$ Long Term Vision \& Planning

3. Risk Awareness \& Mitigation

4. Infrastructure / Resource Support

5. Community Buy-In \& Involvement

6. $\quad$ Work Standards \& Training

7. $\quad$ Marketing \& Publicity

8. Adaptable/ Replicable/Scalable

9. Program/Funding Renewal

10. New Degrees or Certification Programs

11. Job / Wage Impact

12. Link to Positive Economic Outcomes

These sustainability factors were reviewed and discussed with WSW executives and grant recipients at a WSW Sustainability conference at East Stroudsburg University in the spring of 2009. From this meeting, the same 12 sustainability factor groupings of 23 sustainability characteristics (now worded as questions) emerged unchanged.

\section{Behaviorally Anchored Rating Scale (BARS)}

The LVRC team next decided that, in order to be practically useful as a measurement of sustainability (of WSW grantee work activities), the 12 factors/23 questions needed to be converted into a bona fide "Sustainability Index" score. The behaviorally anchored rating scale (BARS) methodology seemed most appropriately suited for this purpose. The idea was to convert each sustainability "question" into a range of important grantee sustainable "behaviors" that could be readily identified and numerically scored.

BARS was developed by Smith and Kendall (1963) as a combination of a graphic rating scale and the critical incident method of rating. In general, the major steps involved in the development of BARS include:

1. Generation of critical incidents

2. Development of performance dimensions

3. Reallocate incidents

4. Scale the incidents

5. Develop final incidents

While BARS has been evaluated and reviewed in a plethora of theoretical and practical venues - and it's utility has been endorsed or criticized (Schwab, Heneman, and DeCotiis, 1975; Tziner, Joanis, and Murphy, 2000) it has generally been found to be useful in many different application areas including student evaluations (McIntyre and Gilbert, 1994), employee appraisals (Rarick and Baxter, 1986), evaluation of pharmacy instruction (Grussing, Valuck, and Williams, 1994), learning organizations (Campbell and Cairns, 1994), evaluation of combat effectiveness (Shapira and Shirom, 1980), and a host of other areas (Govekar and Christopher, 2008).

Using the BARS methodology, a series of "critical incidents" were developed for each of the 23 questions (grouped into 12 factors) in the draft Sustainability Index. A sample BARS scale is shown (Exhibit 1) for each of the three questions developed to assess sustainability factor 1: "Collaboration \& Partnerships" in our WSW Sustainability Index. The rest of the model is embedded in forthcoming results tables.

Prior to implementing the Sustainability Index, one additional step was required. Since it is highly unlikely that all of the 12 sustainability factors are of equal importance in evaluating sustainability of economic development efforts, a mechanism was needed to solicit inputs from sustainability "experts" about relative factor importance, and to translate those inputs into a weighted Sustainability Index. The Analytic Hierarchy Process (AHP) is a mechanism well suited for the task. 


\section{Analytic Hierarchy Process (AHP)}

The Analytic Hierarchy Process (AHP) is a theory of measurement through pairwise comparisons of variables or dimensions and relies on the judgments of experts to determine the relative importance of each variable / dimension. AHP was originally developed by Saaty (1977) as a decision making method for prioritizing alternatives when multiple criteria must be considered. It has been used in a wide variety of decision areas, including R\&D project selection (Liberatore, 1987, 1988); evaluating alternative product formulations (Liberatore and Nydick, 1990; selecting a microcomputer (Arbel and Seidmann, 1994) and a host of other applications. A thorough review of the AHP literature was conducted by Forman and Gass (2001). They examine the history and development of AHP and conclude that "AHP is perhaps, the most widely used decision making approach in the world today. It's validity is based on the many hundreds (now thousands) of actual applications in which the AHP results were accepted and used..." (p 4).

The AHP process can be described by the following example steps adopted from Nydick and Hill (1972) to suit our sustainability factor application:

1. Specify the set of criteria (factors) for evaluating the sustainability of grantee project work.

2. Obtain pair-wise comparisons of the relative importance of the factors in achieving sustainability and compute the priorities or weights of the factors based on this information.

3. Using the results of step 2, compute the priorities (i.e., Sustainability Score) for each grantee in achieving the goal of sustainability.

Deploying the AHP decision making methodology with a group of five "economic development sustainability experts" (discussed above) on the 12 sustainability factors resulted in the factor weightings shown in Table 1.

\section{METHODOLOGY}

The WSW Sustainability Index was used to assess the sustainability of the seven WSW grantee projects that were completed (including final report) at the time of this analysis. As such, the seven grants constitute a subgroup of the 52 grants that allow the researchers to introduce and illustrate a viable sustainability assessment methodology. The seven sponsoring organizations and their grant-funded projects are:

1. Kings College's Math Summer Institute

2. Lehigh County Community College's WSW Academy Program

3. Northeast PA Manufacturers and Employers - YES: Your Employment Skills Program

4. $\quad$ People Front \& Center's Financial Competency Models

5. University of Scranton's Financial Literacy Institute

6. Compass Point - Open Court for Entrepreneurs

7. Originate Ventures Internship Program

Hereafter, these projects will be represented by nominal categories (i.e., Grant A through G) presented in a random order other than above in order to maintain confidentiality of the data.

\section{Factor Weightings}

As mentioned, AHP was employed in order to determine the relative importance of each factor. Five researchers involved in the WSW grant and very familiar with the sustainability objective of the grant projects, volunteered to provide pair-wise comparisons of the 12 factors. After determining if, and which, factor was more important, raters evaluated the level of differential importance on a nine-point scale $(1=$ Equally important up to $9=$ Extremely more important, with intermediate anchors of "Moderately", "Strongly" and "Very Strongly" provided for 3, 5, and 7 respectively; even scale values were offered as an option to the raters if greater discrimination was needed). Once all ratings were collected, the factor endorsed as being more important by the majority prevailed as such, and ratings of more importance were averaged and rounded upward to the nearest whole number value. This 
value and its reciprocal were inputted into the initial AHP matrix for analysis and determination of weightings. Simple output weightings (from the AHP process), for each of the Sustainability Factors, are shown in Table 1.

Table 1: AHP Output Producing Sustainability Factor Weights

\begin{tabular}{|l|l|}
\hline \multicolumn{1}{|c|}{ Sustainability factor } & Weighting \\
\hline Collaboration \& Partnerships & .07878 \\
\hline Long Term Vision \& Planning & .05034 \\
\hline Risk Awareness \& Mitigation & .02294 \\
\hline Infrastructure \& Resource Support & .15032 \\
\hline Community Buy -In \& Involvement & .03035 \\
\hline Work Standards \& Training & .06106 \\
\hline Marketing \& Publicity & .03489 \\
\hline Adaptable/Replicable/Scalable & .05078 \\
\hline Program/Funding Renewal & .15971 \\
\hline New Degrees or Certification Programs & .04174 \\
\hline Job/Wage Impact & .16751 \\
\hline Link to Economic Outcomes & .15151 \\
\hline
\end{tabular}

\section{Scoring Grantee Sustainability}

Two researchers carefully reviewed grantee final reports, both narrative and available self reported metrics, that were provided to the WSW administrators. It is important to note that the reports were not written explicitly with the Sustainability Index Framework in mind. Rather, the final reports properly followed the format requested by WSW administration. Thus, researchers at times needed to make careful judgments from these archival documents focusing on what information was available, and careful not to infer beyond the report. Since the sustainability dimensions were not part of the front end structure, the researchers attempted to collect additional data and self report clarification via grantee surveys which are more fully reported elsewhere. Still, it is critical to emphasize that the researchers were steadfast in relying solely on what was reported in the final reports--which varied greatly in their detail, adherence to the WSW format, and specification of supporting evidence for their reported assertions.

In order to calibrate their frames of reference and judgment standards, the researchers reviewed two grants and carefully discussed each of their ratings and the evidence used to formulate those ratings. Where discrepancies existed, researchers resolved what evidence constituted proper or irrelevant evidence and final rating scores were arrived at by discussion to consensus. This initial pilot experience led to the merging of two questions (hence, they were consolidated from 23 to 22), but no other substantive change to the framework was necessary. The process affirmed the clarity of the factors and questions, and helped to ensure stronger reliability of subsequent researcher ratings. For factors where multiple question indicators were used, the ratings were averaged in order to achieve a factor score along the five point scale.

After reviewing the documents for the remaining five grants, each researcher independently generated ratings, which were shared and discussed to consensus. An inter-rater reliability coefficient $\quad(r=0.76, p<.01)$ was obtained for the final sustainability index, and affirmed good consistency between the independent raters using the BARS scale across grantee ratings.

\section{RESULTS}

\section{Sustainability Index scores by Factor}

Sustainability Index Scores by Factor by Grantee are shown in Table 2. As can be seen, by far the most important factors driving sustainability scores across the seven WSW grantees are Program/Funding Renewal and Infrastructure/Resource Support. The weighted factor scores for these two factors are .433 and .419 respectively. The next closest factor was Job/Wage Impact with a weighted factor score of only .269, despite having comparable AHP weightings. 
The lowest weighted factors scores across the grantees was .038 (Risk Awareness \& Mitigation) and .075 (New Degrees \& Certification Programs). The mean weighted factor score was .203 - relatively low given the highest attainable score of .838 for the factor with the highest importance weight (Job or Wage Impact). The wide variability among factor weights suggests some discriminating benefits of using the AHP weighting system by distributing points relative to the importance of the factor.

\section{Sustainability Index Scores by Question}

Table 3 shows mean scores by question along with question score rankings out of the 22 total questions. As can be seen, question scores ranged from a high of 3.86 (of 5) for question 13 - "Does the grant work develop processes, tools, programs that are easily modified and replicated across NEPA counties?" to a low of 1.21 for question 20 - "Does the grant result in higher wages for workers in the financial services industry?" The mean score for all 22 questions was 2.47 on a scale from one to five.

Two additional question scores seemed high across the 7 grantees: question 1 - "Does the grantee form any long term partnerships?" (mean $=3.50$ ) and question 8 -"Does grant reach out and include as many local stakeholders as possible in grant activities?" (mean = 3.50). The two lowest scoring questions were question $20-$ "Does the grant result in higher wages for workers in the financial services industry?" (mean = 1.21) and question 17 - "Does the grant deliver new market based financial services degrees offered to the public?" (mean $=1.36)$.

\section{Sustainability Index Scores by Grantee}

The seven grantees scored relatively low on the Sustainability Index. Given a maximum score attainable of 5.0, the mean weighted sustainability score was 2.43 with a $\mathrm{min} / \mathrm{max}$ range of 1.78 to 3.12 . The highest scoring grantee was Grantee A with a score of 3.12. Grantee B scored a 2.87; the balance of grantees scored considerably lower. Grantee $\mathrm{C}$ was the lowest scoring grantee with a weighted sustainability index score of 1.78 . Table 2 shows both un-weighted (raw) and weighted sustainability scores. Note that the rank order of the grantees remains the same (from raw to weighted scores) with the exception of Grantee D and Grantee E. They swapped sustainability rankings ( $\mathrm{D}$ from $3^{\text {rd }}$ to $5^{\text {th }}$ and $\mathrm{E}$ from $5^{\text {th }}$ to $3^{\text {rd }}$ ) once the factor importance weights were applied to generate the weighted sustainability scores.

\section{Significant Grantee Outliers on Sustainability}

As indicated above (and listed in Tables 2 and 3), Grantee A and Grantee B scored the highest on the Sustainability Index. Their weighted sustainability scores are shown in detail in Tables 4 and 5 respectively.

A's (overall highest) 3.12 score is due to its BARS ratings on the more heavily weighted factors (Program or Funding Renewal; Infrastructure \& Resource Support shown in Table 4). In particular, question 15 (Does the grant result in institutionalization of program processes, tools, or initiatives?) shows a maximum score of 5 .

Grantee B's detailed scores for Program or Funding Renewal and for Infrastructure \& Resource Support (Table 5) show that question 15, again, scored high (4.5 of 5.0) and question 7 ("Does grant focus on, and plan for, strategic resources (people, equipment, technology) needed for long term success?") also scored 4.5. Question 7 is the single most significant question driving scores on the Infrastructure and Resource Support factor.

On the low end, Tables $2 \& 3$ show that grantee Grantee $\mathrm{C}$ scored lowest on the Sustainability Index. C scored well below 3 on the raw BARS scale on 9 of 12 factors. The other 3 factors, Work Standards \& Training, Adaptable/Flexible/Scalable, and Long Term Vision and Planning, all scored 3.0 for Grantee C. In addition, Grantee $\mathrm{C}$ did not score well on any of the most important (top weighted) sustainability factors - Job or Wage Impact (.168), Program or Funding Renewal (.266), Link to Economic Outcomes (.152), or Infrastructure or Resource Support (.376). 


\section{DISCUSSION}

Faced with the challenge of assessing continued sustainability of grant projects nearing the end of their funding cycle, the impact assessment team researched, designed and implemented a Sustainability Index measurement model. The evaluation objective was predicated on a sustainability definition specific to region-based efforts at impacting an industry, in this case the financial service sector within NEPA. The purpose of this research paper was to analyze and disseminate information about the innovative model and measurement tool created to assess the potential sustainability of funded grant projects. The Sustainability Index was featured, but also illustrated using a sample of seven grant projects designed to impact the financial service industry within a regional area. Psychometric highlights of the model were its reliance on BARS-oriented methodology for scoring grant projects, and the weighting of factor scores via AHP analyses.

Results were shared at three levels of analysis: by factor, by specific question, and by grant projects. At each level, the results shed light on the quality of the model and illustrated the use of the model in a particular grant funding context, the WSW initiative.

\section{Factor}

At the factor level, clearly some of the dimensions are not universal to all types of grant projects (e.g., link to economic outcomes; job/wage impact). However, there may be comparable dimensions that would fittingly substitute for any given project domain. The current model would likely generalize to the vast majority of grant funding initiatives targeting financial, labor or economic objectives within a geographical region. The actual reported results by factor for the WSW project suggest that the sustainability of this particular initiative will best be served by the grant's collective efforts at anticipating and generating the need for program/funding renewal, as well as securing infrastructure/resource support. The emergence of these two factors is comparable to the findings by Cutler (2002) in assessing the sustainability predictors for grant initiatives targeting positive change among children in low income communities. In their post-initiative interviews with grant participants, Cutler's research team found that, "The sustainability challenge frequently involves not just keeping participants active but ensuring that the heart of the effort-its goals, strategies, and commitment - remains intact." Particularly, their respondents urged this be achieved by "making sure that the core ideas - collaboration, prevention, equal opportunity - are assimilated into the thinking of individuals and the practices of organizations." (p. 10). These themes were also highlighted in their future recommendations which emphasized anticipating the needed capacity to be built into the organization and consistent focus on conceptualizing the proper funding structure needed to actively pursue resources.

\section{Factor Questions}

Most of the sustainability factors posed multiple questions as indicators of the factor's status. This allowed the model to recognize the complexity and multifaceted nature of some of the factors, while keeping the model appropriately parsimonious. Question data illustrate the model's ability to capture nuances and meaningful insights about the particular grant project. The three questions with the highest reported results (replication across counties, long term partnerships, and inclusion of local stakeholders) seem to reflect WSW's strategic emphasis on regional collaboration, which served as strong screening criteria for grant funding (WSW, 2008). The lower question scores (wage impact and the creation of financial service degrees) reflect the negative impact of the coinciding recession and the short-term timing of the impact assessment relative to the funding of the grants.

\section{Grantee}

Despite some restriction in the range of sustainability scores among the grant projects, the model was still sensitive enough to discern relative differences between the projects in terms of sustainability potential. In the current initiative, it is apparent that two grantees (A and B) had implemented effective strategies that enabled them to address some of the sustainability factors deemed important by the AHP weights, particularly Program/Funding Renewal and Infrastructure/Resource Support. 


\section{External Validation of Findings}

Seven months after the end of the WSW grant period, an attempt was made to seek external validity of two key findings in the study:

1) Program/funding renewal and Infrastructure and resource support played a critical role in the sustainability of WSW grant activities.

2) Grantee A and Grantee B were significantly more successful in engaging in sustainable grant activities than grantees scoring lowest on the Sustainability Index.

For finding number 1, original interview records of WSW executives (familiar with grantee work) were reviewed in search of specific references to the importance of these factors. Table 6 shows a significant amount of reference from four of the WSW executives interviewed. This data clearly provides some credence to the importance of these variables in fostering sustainability of grant work in the WSW project space in NEPA.

For the second finding, the top two highest scoring grantees (A and B) on the Sustainability Index (from Table 2) were compared to the bottom two scoring grantees ( $F$ and $C$ ) using a simple six question follow up questionnaire. Table 7 shows a summary of responses from this ( 7 month later) search for external validity. Again, the data, while not overwhelming, clearly show that grantees A and B discussed evidence that their programs were far more sustainable than grantees $\mathrm{F}$ and $\mathrm{C}$. This provides some external validity to the data reported using the Sustainability Index developed for the WSW research.

\section{CONCERNS AND LIMITATIONS}

We should report some concerns and limitations of the current dissemination and use of the model. First, the timeline of our required assessment relative to the status of the projects was less than ideal. The necessary deadlines confronting the impact assessment team meant that only a few grants could be evaluated, assessment relied at some level on inferences of data provided via pre-structured reporting documents not designed by the researchers, and virtually no lag time to validate the actual sustainability of the project.

Second, the BARS anchors provided greater specificity by mandating certain levels of evidence for each question, but the specific type of evidence was not individualized for each question. Much of this concern was addressed by the careful calibration process by the collaborating evaluators. Ideally, future work could develop specific criteria within each factor which would further optimize the BARS approach (Tziner, Joanis, \& Murphy, 2000).

Finally, although the inter-rater reliability for the two researchers providing scores on the sustainability model's questions for each grant was strong, there was much wider variation by experts during the AHP process. This may reflect some varying levels of familiarity with the model and specific grant project; but it can be asserted that the healthy number of participants, five, would allow sufficient reliability when expert comparison of factor importance was aggregated.

\section{FUTURE DIRECTIONS - A CALL TO ACTION}

Preferably, as prescribed by other experiences and lessons learned (Brown \& Kraft, 2008), careful consideration of sustainability should take place throughout such projects - including the planning, implementation, and evaluation phases. The experience with, and results of the Sustainability Index scores of a subset of grants within the WSW initiative suggest that the model is ripe with potential. We encourage and support greater use of the model in order to achieve further refinements, improvements and wider application. Sustainability provides a direct connection to three important project outcomes: return on investment, nurturing and monitoring long-term trickle effects for projects that place a strong emphasis on regional collaboration, as well as the increased accountability compliance placed on all funding systems. Therefore, the Sustainability Index model, shared herein, should be given increased attention as a necessary, supplement to an impact assessment strategy for grant projects desiring long term results. 


\section{AUTHOR'S NOTE}

The WSW workforce solution was funded by a grant awarded under Workforce Innovation in Regional Economic Development (WIRED) as implemented by the U.S. Department of Labor's Employment and Training Administration. The solution was created by the Lehigh Valley Research Consortium (LVRC) and does not necessarily reflect the official position of the U.S. Department of Labor. The Department of Labor makes no guarantees, warranties, or assurances of any kind, express or implied, with respect to such information, including any information on linked sites and including, but not limited to, accuracy of the information or its completeness, timeliness, usefulness, adequacy, continued availability, or ownership.

\section{AUTHORS' INFORMATION}

David M. Gilfoil, Ph.D., is currently the Director of the Global MBA Program at DeSales University where he teaches a variety of Sales \& Sales Management, Marketing, Management, Consumer Behavior, and Global Business Ethics courses. Prior to joining DeSales in 2007, he served as Managing Director and President of Agere Systems Japan, and has held numerous management positions at Agere Systems, Lucent Technologies, and AT\&T. Gilfoil earned a Bachelor of Arts degree in Psychology from University of Massachusetts, a Master's degree in Experimental and Cognitive Psychology from the College of William \& Mary, and a Doctorate in Management science from Stevens Institute of Technology.

Robert T. Brill, Ph.D., is an associate professor of Industrial / Organizational Psychology at Moravian College having completed his graduate work at Virginia Tech. He teaches a variety of courses, and conducts research in pedagogy, work-life challenges and professional development among nurses. He has conducted training in the areas of communication, stress management, as well as employee well-being at a variety of organizations. A member of the Society for Industrial / Organizational Psychology and the Association for Psychological Science, Bob served as the Research Director for a grant supported by the Department of Labor's Workforce Innovations in Regional Economic Development (WIRED) initiatives.

\section{REFERENCES}

1. Arbel, A. \& Seidmann, A.. (2003). On Sustainability of Project Innovations as Systemic Changes. Journal of Educational and Psychological Consultation, 14(1), 1-25.

2. Brown, Deryck. (1998). Evaluating Institutional Sustainability in Development Programmes: Beyond Dollars and Cents. Journal of International Development, 10(1), 55-69.

3. Brown, Lawrence D. \& Kraft, M. Katherine (2008). Active Living as an Institutional Challenge: Lessons from the Robert Wood Johnson Foundation's "Celebrate Fitness" Program. Journal of Health Politics, Policy \& Law, 33(3), 497-523.

4. Campbell, T. \& Cairns, H. (1994). Developing and measuring the learning organization. Industrial and Commercial Training, 26(7/8), 10-15.

5. Cutler, I. (2002). End Games: The Challenge of Sustainability. Baltimore, MD: The Annie E. Casey Foundation.

6. Forman, Ernest H., \& Gass, Saul I. (2001). The Analytic Hierarchy Process - An Exposition. Operations Research, 49(4), 469-486.

7. Found, Pauline, Beale, Jo, \& Rich, Nick (2006). Theoretical Model for Sustainable Change. Cardiff Logistics and Operations Management.

8. Govekar, Paul L., \& Christopher, Jill Ellen R. (2008). Assessing Academic Advising Using Behaviorally Anchored Rating Scales (BARS). College of Business Administration, Ohio Northern University.

9. Grussing, Paul, Valuck, Robert, \& Williams, Reed. (1994). Development and Validation of BehaviorallyAnchored Rating Scales for Student Evaluation of Pharmacy Instruction. American Journal of Pharmaceutical Education, 58, 25-37.

10. Liberatore, Matthew J. (1987). An Extension of the Analytic Hierarchy Process for Industrial R\&D Project Selection and Resource Allocation. IEEE Transactions on Engineering Management, 34(1), 12-18.

11. Liberatore, Matthew J. (1988). A Decision Support System Linking Research and Development Project Selection with Business Strategy. Project Management Journal, 19 (5), 14-21. 
12. Liberatore, Matthew J., \& Nydick, Robert L. (1990). An Analytic Hierarchy Approach for Evaluating Product Formulations. Computer Aided Formulation: A Manual for Implementation, 179-94.

13. McIntyre, F.S. \& Gilbert, F.W. (1994). Improving performance in case courses: An argument for behaviorally anchored rating scales. Marketing Education Review, 4, 31-58.

14. Miller, Clark A. (2005). New Civic Epistemologies of Quantification: Making Sense of Indicators of Local and Global Sustainability. Science, Technology, \& Human Values, 30(3), 403-432.

15. Nydick, Robert L. \& Hill, Ronald Paul. Using the Analytic Hierarchy Process to Structure the Supplier Selection Procedure. International Journal of Purchasing and Materials Management, 28(2), 31-36.

16. Rarick, C.A. \& Baxter, G. (1986). Behaviorally Anchored Rating Scales (BARS): An effective performance appraisal approach. SAM Advanced Management Journal, 51(1), 36-39.

17. Saaty, T.L. (2008). Decision Making with the analytic hierarchy process. International Journal of Services Sciences, 1(1), 83-88.

18. Scheirer, Mary Ann. (2005). Is Sustainability Possible? A Review and Commentary on Empirical Studies of Program Sustainability. American Journal of Evaluation, 26(3), 320-347.

19. Schwab, D.P., Heneman III, H.G., \& DeCotiis, T.A. (1975). Behaviorally anchored rating scales: A review of the literature. Personal Psychology, 28, 549-562.

20. Shapira, Zur \& Shirom, Arie. (1980). New Issues in the Use of Behaviorally Anchored Rating Scales: Level of Analysis, the Effects of Incident Frequency, and External Validation. Journal of Applied Psychology, 65(5), 517-523.

21. Shediac-Rizkallah, Mona \& Bone, Lee. (1998). Planning for the Sustainability of Community-Based Health Programs: Conceptual Frameworks and Future Directions for Research, Practice, and Policy. Health Education Research, 13(1), 87-104.

22. Smith, P.C. \& Kendall, L.M. (1963). Retranslation of Expectations: An approach to the construction of unambiguous anchors for rating scales. Journal of Applied Psychology, 47, 149-155.

23. Tziner, A., Joanis, C., \& Murphy, K.R. (2000). A comparison of three methods of performance appraisal with regard to goal properties, goal perception, and rate satisfaction. Group \& Organizational Management, 25(2), 175-190.

24. Van Marrewijk, M. (2003). Concepts and Definitions of CSR and Corporate Sustainability: Between Agency and Communion. Journal of Business Ethics, 44(2/3), 95.

25. Wall Street West. (2008). WIRED Regional Implementation Plan. Report created by Wall Street West, Bethlehem, PA.

26. Yilmaz, A.K. (2008). The Corporate Sustainability Model for Airline Business. European Journal of Scientific Research, 22(3), 304-317 
Exhibit 1: Sample Bars Scale - Collaboration And Partnerships Factor

\begin{tabular}{|c|c|c|c|}
\hline $\begin{array}{c}\text { Collaboration and } \\
\text { Partnerships }\end{array}$ & Bars & Score & Comments \\
\hline $\begin{array}{l}\text { 1. Does the grantee } \\
\text { form any long } \\
\text { term partnerships/ }\end{array}$ & $\begin{array}{l}5 \text { - Multiple long term partnerships have been formed directly as a } \\
\text { result of grant activities } 3 \text { - Some evidence of formal } \\
\text { collaboration, partnerships formed, or existing partnerships } \\
\text { strengthened } \\
1 \text { - No evidence of any stated or observed collaboration or } \\
\text { partnerships linked to grant activities }\end{array}$ & & \\
\hline $\begin{array}{l}\text { 2. Have grantees } \\
\text { collaborated with } \\
\text { each other to seek } \\
\text { more funding or } \\
\text { support? }\end{array}$ & $\begin{array}{l}5 \text { - Grantee has collaborated with other grantees and obtained } \\
\text { additional funding to sustain grant activities } \\
3 \text { - Some evidence of formal collaboration for funding requests } \\
1 \text { - No evidence of any stated or observed collaboration to seek } \\
\text { additional funding }\end{array}$ & & \\
\hline $\begin{array}{l}\text { 3. Have grantees } \\
\text { partnered with } \\
\text { local WIB (or } \\
\text { regional } \\
\text { planning/governa } \\
\text { nce boards) for } \\
\text { ongoing } \\
\text { referrals/support } \\
\text { of program? }\end{array}$ & $\begin{array}{l}5 \text { - Grantee has partnered with local or regional boards to ensure } \\
\text { ongoing support of grant program } \\
3 \text { - Some evidence that grantee has engaged } \\
\text { local or regional boards to solicit their support of future grant } \\
\text { related activities } \\
1 \text { - No evidence of any stated or observed interaction with local or } \\
\text { regional boards to support/continue program }\end{array}$ & & \\
\hline
\end{tabular}




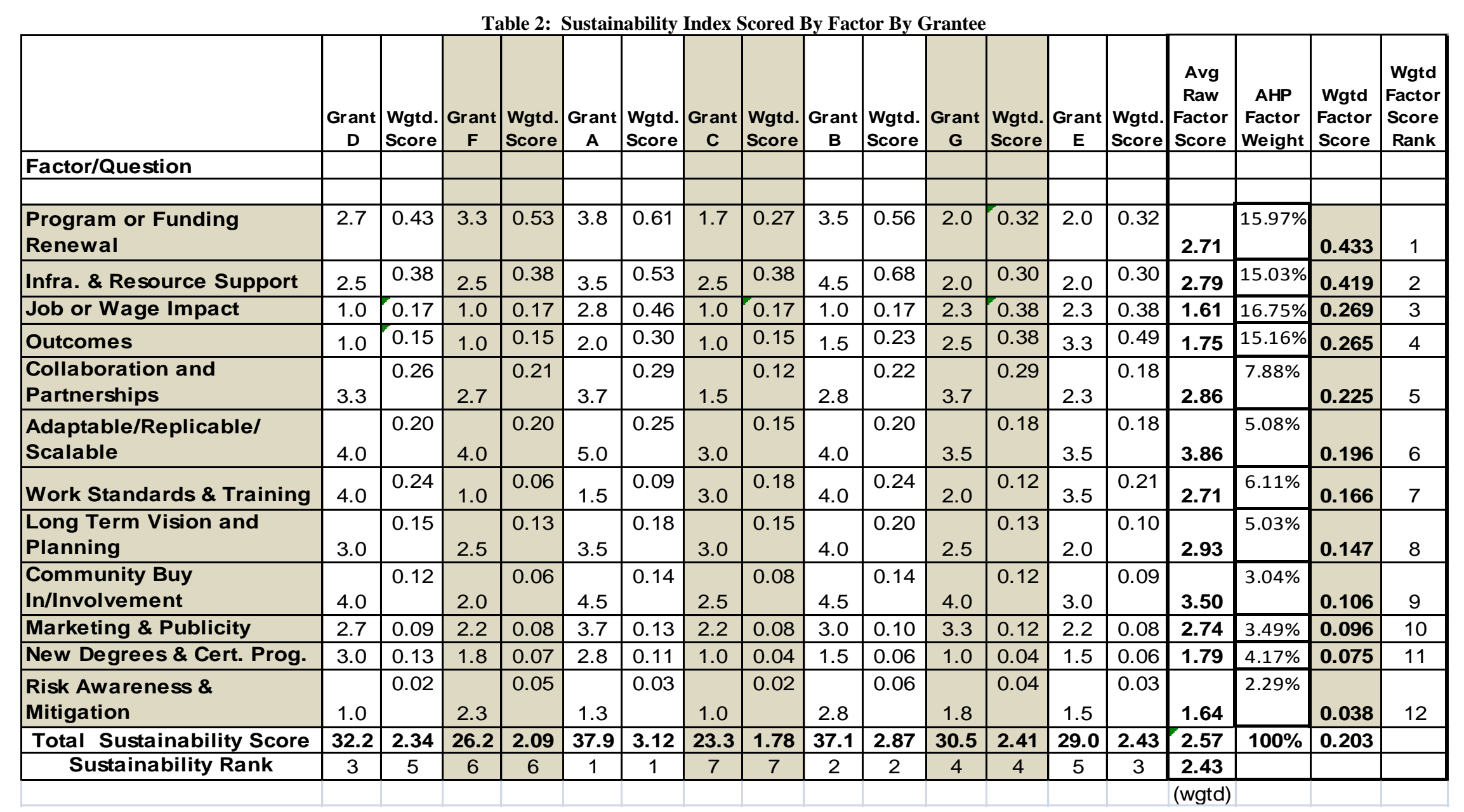




\begin{tabular}{|c|c|c|c|c|c|c|c|c|c|}
\hline & $\underset{\text { D }}{\text { Grant }}$ & $\underset{F}{\text { Grant }}$ & $\underset{\text { A }}{\text { Grant }}$ & $\begin{array}{l}\text { Grant } \\
\text { C }\end{array}$ & $\underset{\text { B }}{\text { Grant }}$ & $\underset{\text { Grant }}{\text { Grant }}$ & $\underset{E}{\operatorname{Grant}}$ & $\begin{array}{l}\text { Avg } \\
\text { Score }\end{array}$ & $\begin{array}{l}\text { Question } \\
\text { Rank }\end{array}$ \\
\hline \multicolumn{10}{|l|}{ Sustainability Factor/Question } \\
\hline \multicolumn{10}{|l|}{ I Collaboration and Partnerships } \\
\hline 1. Does the grantee form any long term partnerships? & 4 & 3 & 3.5 & 2.5 & 4 & 4.5 & 3 & 3.50 & 2 \\
\hline $\begin{array}{l}\text { 2. Have grantees collaborated with each other to seek more funding or } \\
\text { support? }\end{array}$ & 3 & 2 & 3.5 & 1 & 2 & 3 & 2 & 2.36 & 12 \\
\hline $\begin{array}{l}\text { 3. Have grantees partnered with local WIB (or regional } \\
\text { planning/governance boards) for ongoing referrals/support of } \\
\text { program? }\end{array}$ & 3 & 3 & 4 & 1 & 2.5 & 3.5 & 2 & 2.71 & 10 \\
\hline \multicolumn{10}{|l|}{ II Long Term Vision and Planning } \\
\hline $\begin{array}{l}\text { 4. Does the grant produce viable long term vision, goals, and } \\
\text { objectives that extend beyond the grant? }\end{array}$ & 3 & 2.5 & 3.5 & 3 & 4 & 2.5 & 2 & 2.93 & 8 \\
\hline \multicolumn{10}{|l|}{ III Risk Awareness \& Mitigation } \\
\hline $\begin{array}{l}\text { 5. Have grantees assessed risks associated with grant and developed } \\
\text { a mitigation plan? }\end{array}$ & 1 & 3 & 1 & 1 & 3 & 2.5 & 1.5 & 1.86 & 17 \\
\hline 6. Does the grant include succession planning? & 1 & 1.5 & 1.5 & 1 & 2.5 & 1 & 1.5 & 1.43 & 20 \\
\hline \multicolumn{10}{|l|}{ IV Infrastructure \& Resource Support } \\
\hline $\begin{array}{l}\text { 7. Does grant focus on, and plan for, strategic resources (people, } \\
\text { equipment, technology) needed for long term success? }\end{array}$ & 2.5 & 2.5 & 3.5 & 2.5 & 4.5 & 2 & 2 & 2.79 & 9 \\
\hline \multicolumn{10}{|l|}{ V. Community Buy In and Involvement } \\
\hline $\begin{array}{l}\text { 8. Does grant reach out and include as many local stakeholders as } \\
\text { possible in grant activities? }\end{array}$ & 4 & 2 & 4.5 & 2.5 & 4.5 & 4 & 3 & 3.50 & 2 \\
\hline \multicolumn{10}{|l|}{ VI Work Standards \& Training } \\
\hline $\begin{array}{l}\text { 9. Does the grant include workforce training or permanent changes to } \\
\text { financial industry work standards? }\end{array}$ & 4 & 1 & 1.5 & 3 & 4 & 2 & 3.5 & 2.714 & 10 \\
\hline \multicolumn{10}{|l|}{ VII Marketing \& Publicity } \\
\hline $\begin{array}{l}\text { 10. Does the grant gather and disseminate best practices about the } \\
\text { financial services industry? }\end{array}$ & 3 & 1.5 & 4 & 4 & 3 & 3.5 & 2.5 & 3.07 & 5 \\
\hline $\begin{array}{l}\text { 11. Does the grant produce exceptional leadership or motivators as } \\
\text { role models? }\end{array}$ & 3.5 & 2 & 3 & 1.5 & 4 & 4 & 3 & 3.00 & 6 \\
\hline $\begin{array}{l}\text { 12. Does the grant provide a strategic marketing plan (including } \\
\text { customer segments and promotional elements) to raise awareness of } \\
\text { the program? }\end{array}$ & 1.5 & 3 & 4 & 1 & 2 & 2.5 & 1 & 2.14 & 14 \\
\hline VIII Adaptable/Replicable/ Scalable & & & & & & & & & \\
\hline
\end{tabular}


Table 3: Sustainability Factor By Question By Grantee (Cont).

13.Does the grant work develop processes, tools, programs that are easily modified and replicated across NEPA counties?

IX Program or Funding Renewal

14. Does the grant create sustaining or endowment type funding?

15. Does the grant result in institutionalization of program processes,

tools, or initiatives?

16. Does the grant set up processes to provide continuous access to resources after the program goes away? $X$ New Degrees \& Certification Programs

17. Does the grant deliver new market based financial services degrees offered to the public?

18. Does the grant result in the certification of faculty (to teach) or graduates (to work) in the financial services industry?

XI Job or Wage Impact

19. Does the grant result job creation/retention in the financial services workforce?

20. Does the grant result in higher wages for workers in the financial services industry?

\section{Outcomes}

21. Did the grant have a positive ROI, increase local tax revenues or otherwise positively contribute to individual or corporate financials? 22. Did the grant improve productivity?

\begin{tabular}{|c|c|c|c|c|c|c|c|c|c|}
\hline & 4 & 4 & 5 & 3 & 4 & 3.5 & 3.5 & 3.86 & 1 \\
\hline & 2.5 & 2 & 3 & 1 & 2 & 2 & 1 & 1.93 & 16 \\
\hline & 3 & 4 & 5 & 1.5 & 4.5 & 2 & 2.5 & 3.21 & 4 \\
\hline & 2.5 & 4 & 3.5 & 2.5 & 4 & 2 & 2.5 & 3.00 & 6 \\
\hline & 3 & 1 & 1 & 1 & 1 & 1 & 1.5 & 1.36 & 21 \\
\hline & & & & & & & & & \\
\\
\hline
\end{tabular}




\begin{tabular}{|c|c|c|c|c|c|}
\hline & Grant A & $\begin{array}{l}\text { Factor } \\
\text { Weight }\end{array}$ & $\begin{array}{l}\text { Wghtd } \\
\text { Factor } \\
\text { Score }\end{array}$ & $\begin{array}{l}\text { Ques. } \\
\text { Rank }\end{array}$ & $\begin{array}{c}\text { Factor } \\
\text { Rank }\end{array}$ \\
\hline \multicolumn{6}{|l|}{ Sustainability Factor/Question(s) } \\
\hline \multicolumn{6}{|l|}{ IX Program or Funding Renewal } \\
\hline 14. Does the grant create sustaining or endowment type funding? & 3 & & & 16 & \\
\hline $\begin{array}{l}\text { 15. Does the grant result in institutionalization of program processes, tools, or } \\
\text { initiatives? }\end{array}$ & 5 & & & 4 & \\
\hline $\begin{array}{l}\text { 16. Does the grant set up processes to provide continuous access to resources after } \\
\text { the program goes away? }\end{array}$ & 3.5 & & & 6 & \\
\hline $\begin{array}{ll}\text { Program or Funding Renewal Score } \\
\end{array}$ & 3.83 & $15.97 \%$ & 0.612 & & 1 \\
\hline \multicolumn{6}{|l|}{ IV Infrastructure \& Resource Support } \\
\hline $\begin{array}{l}\text { 7. Does grant focus on, and plan for, strategic resources (people, equipment, } \\
\text { technology) needed for long term success? }\end{array}$ & 3.50 & & & 9 & \\
\hline Infrastructure \& Resource Support & 3.50 & $15.03 \%$ & 0.526 & & 2 \\
\hline
\end{tabular}


Table 5: Grant B Sustainability Scores For Factors Iv And Ix (By Question)

\begin{tabular}{|c|c|c|c|c|c|}
\hline & Grant B & $\begin{array}{l}\text { Factor } \\
\text { Weight }\end{array}$ & $\begin{array}{l}\text { Wghtd } \\
\text { Factor } \\
\text { Score }\end{array}$ & $\begin{array}{l}\text { Ques. } \\
\text { Rank }\end{array}$ & $\begin{array}{c}\text { Factor } \\
\text { Rank }\end{array}$ \\
\hline \multicolumn{6}{|l|}{ Sustainability Factor/Question(s) } \\
\hline \multicolumn{6}{|l|}{ IX Program or Funding Renewal } \\
\hline 14. Does the grant create sustaining or endowment type funding? & 2 & & & 16 & \\
\hline 15. Does the grant result in institutionalization of program processes, tools, or initiatives? & 4.5 & & & 4 & \\
\hline $\begin{array}{l}\text { 16.Does the grant set up processes to provide continuous access to resources after the } \\
\text { program goes away? }\end{array}$ & 4 & & & 6 & \\
\hline Program or Funding Renewal Score & 3.50 & $15.97 \%$ & 0.559 & & 1 \\
\hline \multicolumn{6}{|l|}{ IV Infrastructure \& Resource Support } \\
\hline $\begin{array}{l}\text { 7. Does grant focus on, and plan for, strategic resources (people, equipment, technology) } \\
\text { needed for long term success? }\end{array}$ & 4.50 & & & 9 & \\
\hline Infras tructure \& Resource Support & 4.50 & $15.03 \%$ & 0.676 & & 2 \\
\hline
\end{tabular}


Table 6: Factor Iv \& Ix - External Validity Comments From Wsw Interviews

\begin{tabular}{|c|c|c|}
\hline WSW Interviewee & Factor IV - Infrastructure/Resource Support & Factor IX - Program Funding \& Renewal \\
\hline Interview Source 1 & $\begin{array}{l}\text { - Since grantees may need continuous support, a credible organization } \\
\text { with a regional perspective is needed for sustaining the WSW } \\
\text { project }\end{array}$ & $\begin{array}{l}\text { - Lag time in funding release caused problems for many grantees - } \\
\text { they cannot spend all of their funds in time; this needs to be fixed. }\end{array}$ \\
\hline Interview Source 2 & - WSW lacked staff & $\begin{array}{l}\text { - Founding WSW organizations should be guaranteed funding so that } \\
\text { work can continue. }\end{array}$ \\
\hline Interview Source 3 & $\begin{array}{l}\text { - One key threat to grant sustainability is that some key individuals } \\
\text { left. } \\
\text { - Conflicts in relation to required resources are a key threat to } \\
\text { continued grant work in NEPA. } \\
\text { - Focus groups indicated that the grantee programs would need to } \\
\text { provide access to other resources } \\
\text { It is painful for them to consider that the network will not be } \\
\text { sustained after the grant is over without the proper funding and } \\
\text { resource support. }\end{array}$ & $\begin{array}{l}\text { - A language and culture program provided a direct segue to } \\
\text { application for a large federal grant. } \\
\text { - Another key threat to sustainability is clearly when the funding runs } \\
\text { out. } \\
\text { - Some good examples of program funding renewal activities are CD } \\
\text { ROM tools, college credit programs, continuous access to trainers, } \\
\text { process documentation, new curricula, and business templates. }\end{array}$ \\
\hline Interview Source 4 & $\begin{array}{l}\text { - Ownership of the grant work (such as curriculum) by the } \\
\text { organization is critical; you cannot stop it because WSW ends }\end{array}$ & $\begin{array}{l}\text { - Within the focus groups, the top concern to emerge echoed the } \\
\text { interviews concern about much needed funding support. }\end{array}$ \\
\hline
\end{tabular}




\begin{tabular}{|c|c|c|c|c|}
\hline Follow Up Validation Question & Grantee A & Grantee B & Grantee F & Grantee C \\
\hline $\begin{array}{l}\text { 1. Did WSW grant result in products, } \\
\text { services, tools, programs, or degrees } \\
\text { that continue to be offered today? }\end{array}$ & 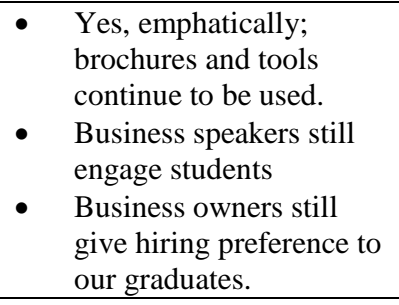 & $\begin{array}{l}\text { - Yes, teachers are using } \\
\text { teaching materials from } \\
\text { this program; our } \\
\text { program taught teachers } \\
\text { to use the financial } \\
\text { curriculum. }\end{array}$ & $\begin{array}{l}\text { No, the work was } \\
\text { sustained for one year } \\
\text { only - all came to a stop } \\
\text { after one year only. }\end{array}$ & $\begin{array}{l}\text { - What is needed is to } \\
\text { translate the model into } \\
\text { practical tools; model is } \\
\text { only available on the } \\
\text { WSW website. }\end{array}$ \\
\hline $\begin{array}{l}\text { 2. Are any of the original people, } \\
\text { equipment, or technology still engaged } \\
\text { in activities or programs related to the } \\
\text { WSW grant? }\end{array}$ & $\begin{array}{l}\text { - Staff have stayed and are } \\
\text { growing; students and } \\
\text { affiliate schools are } \\
\text { growing }\end{array}$ & $\begin{array}{l}\text { - We were able to connect } \\
\text { many schools to Internet } \\
2 .\end{array}$ & $\begin{array}{l}\text { - } \quad \begin{array}{l}\text { No, two main people } \\
\text { have left; no equipment } \\
\text { or tech are still used }\end{array}\end{array}$ & $\begin{array}{l}\text { - Staff are eager to grow } \\
\text { the model but the } \\
\text { funding is not there. }\end{array}$ \\
\hline $\begin{array}{l}\text { 3.Are any grantee team members working } \\
\text { to pursue further grant funding? }\end{array}$ & $\begin{array}{l}\text { - Yes, we are in pursuit of } \\
\text { funds to extend grant } \\
\text { activities. }\end{array}$ & - $\quad$ No & - $\quad$ No & - $\quad$ Not for this model per se. \\
\hline $\begin{array}{l}\text { 4.Did the impact of your WSW grant } \\
\text { change the way financial services } \\
\text { business, education, or training is } \\
\text { conducted in NEPA? }\end{array}$ & $\begin{array}{l}\text { Absolutely. We are a } \\
\text { resource to the financial } \\
\text { community and are } \\
\text { getting more players } \\
\text { involved to promote } \\
\text { financial services to } \\
\text { students. }\end{array}$ & $\begin{array}{l}\text { - Yes, the financial } \\
\text { curriculum is still being } \\
\text { used in school. }\end{array}$ & - $\quad$ No & $\begin{array}{l}\text { - No, not really, but the } \\
\text { potential is there. }\end{array}$ \\
\hline $\begin{array}{l}\text { 5.Did your WSW grant programs have any } \\
\text { other lasting impact on the financial } \\
\text { services industry in NEPA? }\end{array}$ & $\begin{array}{l}\text { - The biggest impact is } \\
\text { student awareness of the } \\
\text { finance industry. }\end{array}$ & $\begin{array}{l}\text { - Difficult to determine at } \\
\text { this point. }\end{array}$ & - $\quad$ No & - No, not really. \\
\hline $\begin{array}{l}\text { 6. Are there any other comments about } \\
\text { grant sustainability you'd like to make; } \\
\text { any factors that you feel impacted the } \\
\text { momentum of your WSW grant project } \\
\text { after the funding ended? }\end{array}$ & $\begin{array}{l}\text { Student employability } \\
\text { has been dramatically } \\
\text { increased due to new } \\
\text { skills acquired. }\end{array}$ & $\begin{array}{l}\text { - We had no difficulty } \\
\text { continuing after grant } \\
\text { funding ended. }\end{array}$ & $\begin{array}{l}\text { - Not really, the } \\
\text { partnership with WSW } \\
\text { was not really a good one }\end{array}$ & $\begin{array}{l}\text { Funding and resources } \\
\text { are needed to develop } \\
\text { practical tools for use. }\end{array}$ \\
\hline
\end{tabular}


NOTES 